\title{
Australian Journal of

\section{The synergistic effect of sewage sludge biochar and Trichoderma harzianum on soybean yield}

\author{
Alyson Silva de Araujo ${ }^{1}$, Luiz Eduardo Bassay Blum², Cícero Célio de Figueiredo ${ }^{1 *}$ \\ ${ }^{1}$ Faculty of Agronomy and Veterinary Medicine, University of Brasília, 70910970 Brasília, DF, Brazil \\ ${ }^{2}$ Department of Plant Pathology, University of Brasília, 70910970 Brasília, DF, Brazil
}

\section{*Corresponding author: cicerocf@unb.br}

\section{Abstract}

The use of sewage sludge to produce biochar is one of the best alternatives for the final destination of this material, allowing for reuse of nutrients and reducing the dependence on mineral fertilizers. Sewage sludge biochar (SSB) stands out as an enhancer of the physical, chemical and biological properties of the soil. The use of beneficial microorganisms such as Trichoderma spp. in combination with biochar may have a synergistic effect on the development of different plants and needs to be better studied. The SSB was produced from sewage sludge biomass (SS) obtained from the sewage treatment plant (STP) of the Federal District Environmental Sanitation Company (CAESB), Brasilia, DF, Brazil. The SSB was produced in an electric tubular furnace at $500{ }^{\circ} \mathrm{C}$ and showed the following characteristics: carbon (19\%), nitrogen (2.3\%), hydrogen (1.7\%), specific surface area $\left(52.5 \mathrm{~m}^{2} \mathrm{~g}^{-1}\right)$, pore volume $\left(0.053 \mathrm{ml} \mathrm{g}^{-1}\right)$. An experiment was carried out in a greenhouse to evaluate the synergistic effect of SSB application (0.5\% $\mathrm{w} / \mathrm{w}$ ) in combination with $T$. harzianum $(\mathrm{TH})$ on soybean development. The treatments adopted were: (1) control - autoclaved soil, (2) TH, (3) SSB and (4) SSB + TH. The SSB was applied 15 days before soybean planting and the TH was applied to the soil two times, once at eight days before planting and the other at the time of planting. The SSB resulted in a $200 \%$ increase in the number of pods when compared to the exclusive application of $T$. harzianum. Application of SSB with $T$. harzianum increased germination by $20 \%$, as well as a $70 \%$ increase in fresh and dry soybean mass in relation to the control. The agronomic indices evaluated in this study demonstrated that the use of SSB in conjunction with $T$. harzianum presents a synergistic effect, allowing for better development of the soybean plants.

Keywords: Glycine max, pyrolysis, biological agent, productivity, soil amendment.

Abbreviations: SS_sewage sludge; SSB_sewage sludge biochar; BCH_biochar; TH_Trichoderma harzianum; STP_sewage treatment plant; PSG_percentage of seed germination

\section{Introduction}

Sewage sludge (SS) is an organic waste that has great potential for use in agriculture. When applied to the soil, SS increases the organic matter $(\mathrm{OM})$ and nutrient content, with emphasis on nitrogen (N) and phosphorus (P). In addition to increasing nutrient availability, SS can improve soil physical and biological properties (Cézar et al., 2012).

Despite the recognized role of SS in soil fertilization, the occurrence of pathogenic microorganisms restricts its use to few locations. Thermal treatment by pyrolysis promotes the elimination of pathogens and dangerous organic compounds (Caballero et al., 1997), and the main product of this process is biochar $(\mathrm{BCH})$.

Studies have shown that $\mathrm{BCH}$ can reduce nutrient losses through leaching (Yuan et al., 2016), provide available nutrients to plants (Furtado et al., 2016; Faria et al. 2018), alkalinize acidic soils (Deenik and Cooney 2016), in addition to innumerable others benefits, favoring improved plant development (Han et al., 2016).

Trichoderma is among the most studied and used biocontrol agents of plant diseases in the world. These free-living and highly interacting microorganisms in the soil, root surfaces and plant tissues (Rajendiran et al., 2010) have antagonistic activity against different phytopathogenic fungi. The inoculation of soybean seeds with $T$. harzianum has resulted in increased plant growth even in soils under saline conditions (Khomari et al., 2018).

In soil, Trichoderma is favored by the presence of organic matter. The use of Trichoderma in combination with organic waste increased the available $P$ levels, and also favored higher carbon fixation in the soil (Shukla et al., 2017). Muter et al. (2017) observed that the application of $\mathrm{BCH}$ together with Trichoderma resulted in increased germination of corn seeds, as well as taller plants.

Considering that $\mathrm{BCH}$ not only provides plant with nutrients but also interferes with the soil microbial, there is still a lack of information regarding the effects of $\mathrm{BCH}$ on the action of beneficial soil organisms. Graber et al. (2010) observed that in soils receiving $\mathrm{BCH}$ there was an increase in the population of Trichoderma spp. in relation to the control soil (without BCH). Hu et al. (2014) also reported changes in composition of the fungi community after application of $\mathrm{BCH}$ to the soil, revealing a proportion of Trichoderma 14.5\% higher than that observed in soil that did not receive $\mathrm{BCH}$. 
Table 1. Physicochemical characteristics of the sewage sludge and biochar.

\begin{tabular}{|c|c|c|}
\hline Characteristics & Sewage sludge & Biochar \\
\hline TC (\%) & 21.0 & 19.0 \\
\hline $\mathrm{TN}(\%)$ & 3.0 & 2.3 \\
\hline $\mathrm{NO}_{3}^{-}\left(\mathrm{mg} \mathrm{kg}^{-1}\right)$ & - & 5.8 \\
\hline $\mathrm{NH}_{4}^{+}\left(\mathrm{mg} \mathrm{kg}^{-1}\right)$ & - & 169.3 \\
\hline $\mathrm{pH}\left(\mathrm{CaCl}_{2}\right)$ & 4.8 & 6.5 \\
\hline$P\left(\mathrm{~g} \mathrm{~kg}^{-1}\right)$ & 35.7 & 61.3 \\
\hline $\mathrm{K}^{+}\left(\mathrm{g} \mathrm{kg}^{-1}\right)$ & 0.8 & 1.2 \\
\hline $\mathrm{Ca}^{+2}\left(\mathrm{~g} \mathrm{~kg}^{-1}\right)$ & 6.6 & 7.8 \\
\hline $\mathrm{Mg}^{+2}\left(\mathrm{~g} \mathrm{~kg}^{-}\right)$ & 0.86 & 1.7 \\
\hline $\mathrm{S}\left(\mathrm{g} \mathrm{kg}^{-1}\right)$ & - & 7.4 \\
\hline $\mathrm{B}\left(\mathrm{mg} \mathrm{kg}^{-1}\right)$ & - & 12.0 \\
\hline $\mathrm{Cu}\left(\mathrm{mg} \mathrm{kg}^{-1}\right)$ & - & 1.1 \\
\hline $\mathrm{Fe}\left(\mathrm{mg} \mathrm{kg}^{-1}\right)$ & - & 541 \\
\hline $\mathrm{Mn}\left(\mathrm{mg} \mathrm{kg}^{-1}\right)$ & - & 1.2 \\
\hline $\mathrm{Zn}\left(\mathrm{mg} \mathrm{kg}^{-1}\right)$ & - & 6.2 \\
\hline FA & - & 4.3 \\
\hline $\mathrm{HA}$ & - & 1.1 \\
\hline Humin & - & 95.6 \\
\hline $\mathrm{PV}\left(\mathrm{mL} \mathrm{g}^{-1}\right)$ & - & 0.05 \\
\hline $\operatorname{SSA}\left(m^{2} g^{-1}\right)$ & - & 52.5 \\
\hline Thermotolerant coliforms (a) & - & $<1$ \\
\hline Helminths ${ }^{(b)}$ & - & 0 \\
\hline Moisture content $\left(\mathrm{g} \mathrm{g}^{-1}\right)$ & 0.20 & - \\
\hline Volatile matter $\left(\mathrm{g} \mathrm{g}^{-1}\right)$ & 0.45 & - \\
\hline Ash (\%) & 54 & - \\
\hline
\end{tabular}

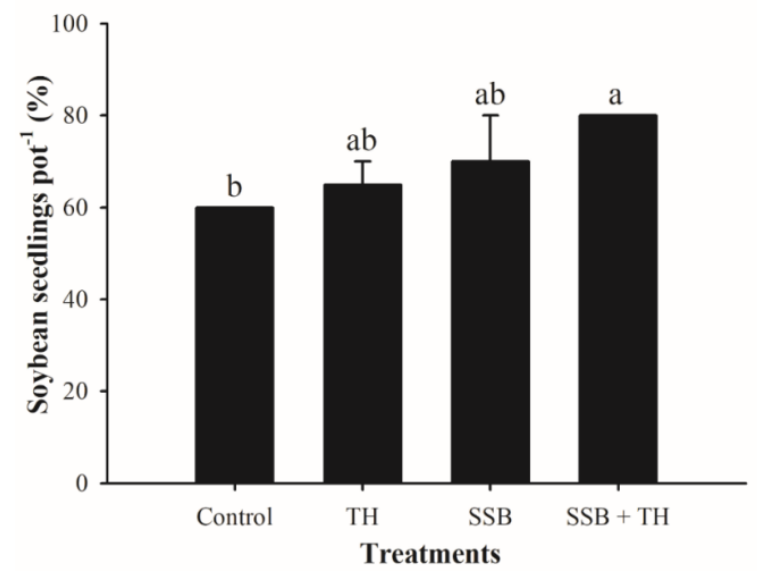

Fig 1. Percentage of soybean seedlings (G. max) per pot in the different treatments (SSB -biochar $500{ }^{\circ} \mathrm{C}, \mathrm{TH}-T$. harzianum). The same letters indicate that there is no significant difference [Duncan's test $(p<0.05)$ ]. The bars indicate standard deviation of the mean.

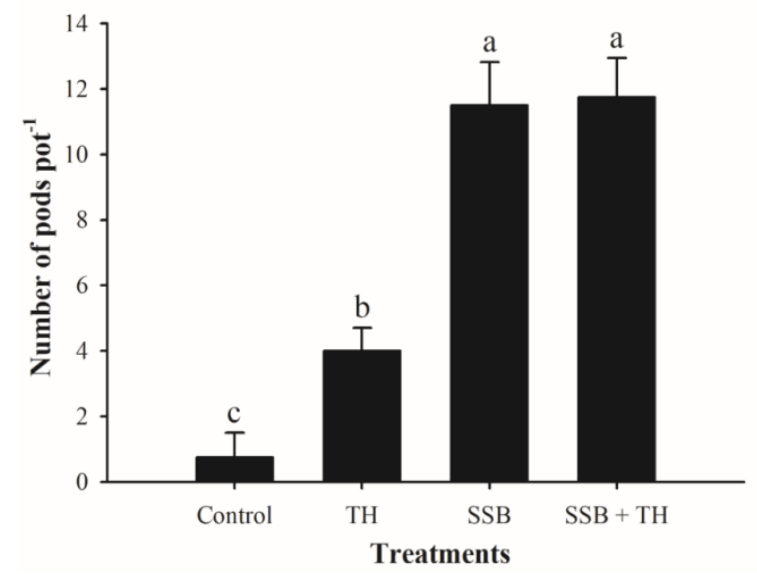

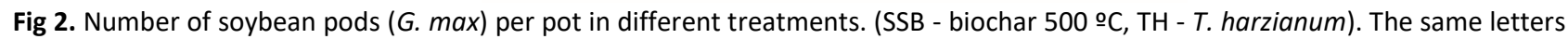
indicate that there is no significant difference [Duncan's test $(p<0.05)$ ]. Bars indicate the standard deviation of the mean. 
(a)

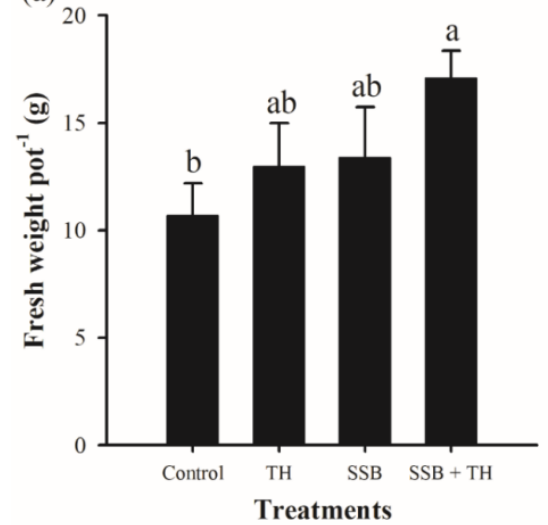

(b)

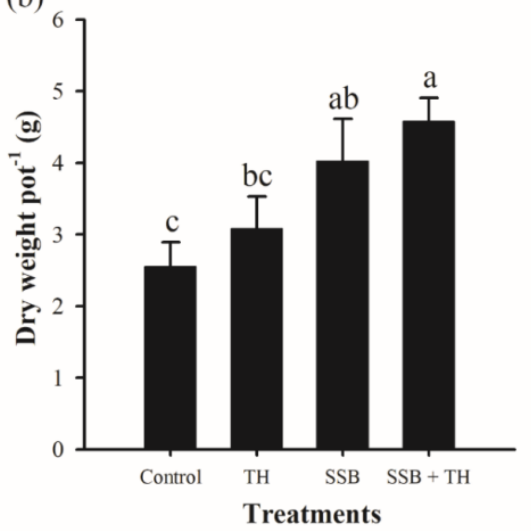

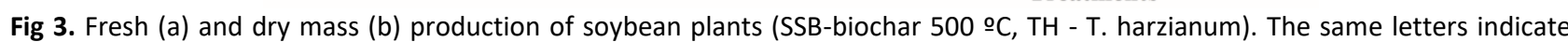
that there is no significant difference [Duncan's test $(p<0.05)$ ]. Bars indicate the standard deviation of the mean.

Additionally, studies suggest that induction or limitation of plant growth occurs by the direct effect of $T$. harzianum on root development, in combination with indirect mechanisms such as solubilization of minerals, including solubilization via acidification, redox, chelation and hydrolysis (Li et al., 2015). In this sense, the combined use of $T$. harzianum must be better understood in order to develop sustainable technology for agricultural use. The objective of this study was to evaluate, using different agronomic indices, the effects of SSB and T. harzianum, applied alone or in combination, on soybean development.

\section{Results and Discussion}

\section{Effect of biochar and T. harzianum on soybean seedlings}

The exclusive application of SSB or T. harzianum to the soil did not increase the germination of soybean seeds compared to the control $(p<0.05)$. However, the combined use of SSB $+T$. harzianum resulted in a $20 \%$ increase in soybean germination in relation to the control (Fig. 1). These results indicate a synergistic effect between SSB and $T$. harzianum that may be the result of compositional changes in the soil microbial community, resulting in an increase in the population of Trichoderma spp. (Graber et al., 2010, Hu et al., 2014). This increase in the Trichoderma population may have favored a greater amount of nutrients in the soil, for example, a possible increase in available $P$ contents (Shukla et al., 2017).

Muter et al. (2017) observed that the application of pelletized biochar from wheat straw together with $T$. viride resulted in higher germination of maize seeds, as well as increased growth (height of plants) in relation to the treatments with biochar and $T$. viride applied alone. The ability of biochar to protect Trichoderma favored its survival in the soil and the direct role of microorganisms on plant growth is indicated as possible explanations for the beneficial effects obtained. Furthermore, there is also the possibility that Trichoderma makes nutrients present in the biochar available to the soil.

\section{Effect of biochar and T. harzianum on number of soybean pods}

Both SSB and T. harzianum increased the number of soybean pods relative to the control. However, SSB stood out and promoted a number of pods $200 \%$ greater than the application of $T$. harzianum alone $(p<0.05)$. The best results are associated with the use of SSB, applied alone or in conjunction with $T$. harzianum, demonstrating its effective capacity to increase soybean production (Fig. 2).

The effects of $\mathrm{BCH}$ addition on crop productivity have previously been demonstrated in several studies. These studies indicate direct and indirect effects of the action of $\mathrm{BCH}$ on crop yield. Kraska et al. (2016) attributed the nutritional effects of $\mathrm{BCH}$ on rye productivity to increased availability of nutrients, including $\mathrm{P}, \mathrm{Mg}$ and $\mathrm{K}$.

Similarly, Ibrahim et al. (2017) justified the higher bean yield to improved soil fertility indicators promoted by the SSB, with a $21 \%$ increase in biomass of the aerial portion and $27 \%$ in the number of fruits. Graber et al. (2014) highlighted the possible effect of $\mathrm{BCH}$ on the rhizospheric system complex, indicated by the interaction between root/soil/pathogen due to a series of physical and chemical properties presented by $\mathrm{BCH}$, including: nutrient content, water retention capacity, redox activity, adsorption capacity, $\mathrm{pH}$ and content of toxic and hormonal compounds, potentially influencing plant development.

\section{Effect of biochar and T. harzianum on the fresh and dry} mass production of soybean plants

The fresh mass and dry mass production of soybean plants showed a strong and positive interaction of SSB with $T$. harzianum (Fig. 3). This synergistic effect guaranteed an increase in soybean plant mass of approximately $70 \%$ in relation to that observed in the control.

Different studies associate the use of $\mathrm{BCH}$ with the increase of nutrients and carbon in the soil, resulting in greater plant development (Abrishamkesh et al., 2015; Faria et al., 2018). Scheifele et al. (2017) verified not only the nutritional effects provided by the biochar when applied to the soil, but also a positive influence on the formation of nodules responsible for biological nitrogen fixation and an increase of dry mass in soybean plants conducted in certain soils with application of $\mathrm{BCH}$ from corn crop remains.

The results of individual application of SSB or T. harzianum did not express a significant increase in fresh plant mass, confirming that combined application of the two products is highly favorable for soybean development.

Seed treatment with $T$. harzianum resulted in an increase in bean plant growth, resulting in greater leaf area, root area 
and higher number of secondary roots (Pereira et al., 2014). Similarly, Trichoderma viride applied to the soil altered the biodynamics of rye plants (Secale cereale L.), increasing the number of leaves in relation to the control (Vecstaudza et al., 2018). The authors observed that use of wood biochar resulted in better survival of Trichoderma spp. during the 35 experimental days, and consequently, better development of the plants.

\section{Materials and Methods}

\section{Acquisition and characterization of the biochar}

The $\mathrm{BCH}$ was produced from SS biomass from the sewage treatment plant (STP) of the environmental sanitation company of the Federal District, Brazil. This STP uses a tertiary treatment system, in which the SS is treated in an upflow anaerobic reactor (UAR), biological reactor and clarifier. The SS used was dried and its characteristics are described in Table 1.

The SSB was produced in an electric tubular furnace (Linn Elektro Therm) at $500{ }^{\circ} \mathrm{C}$, with temperature rise rate equal to $11^{\circ} \mathrm{C} \mathrm{min}-1$ and residence time of 30 minutes. The SS samples were placed in a metal vessel adapted to the internal space of the furnace with a gas and bio-oil exit system, and a mechanism that restricts the flow of oxygen. The physicochemical characteristics of the SSB are presented in Table 1.

The SSB surface areas and pore volumes were determined by $\mathrm{N}_{2}$ adsorption isotherms at $-196.2{ }^{\circ} \mathrm{C}$ in a surface area analyzer, NOVA 2200. Total C, N and $\mathrm{H}$ contents in the SSB were determined using a $\mathrm{CHN}$ Elemental analyzer. The $\mathrm{pH}$ was determined in $\mathrm{CaCl}_{2} 0.01 \mathrm{M}$ solution, using a $1: 5(\mathrm{w} / \mathrm{v})$ biochar:solution ratio suspension. Electrical conductivity (EC) was measured in a $1: 10\left(\mathrm{~g} \mathrm{~mL}^{-1}\right)$ ratio using a conductivity meter. Dried and ground samples were subjected to acid digestion according to USEPA3050B. Macro and micronutrient contents were determined after nitricperchloric acid digestion. Nitrate and ammonium were determined by the Kjeldhal method. Humic substances were extracted with a $\mathrm{NaOH} 0.1 \mathrm{M}$ solution. Total coliforms were determined according to American Public Health Association - APHA and the number of helminth eggs was obtained according to Ayres (1991).

\section{Implantation and conduction of the experiment in a greenhouse}

The study was conducted in a greenhouse and the development of soybean (Glycine max) cultivated in pots was evaluated. For the assay, soybean seeds of cultivar P98C81 were used. Sowing of the soybeans occurred in $4 \mathrm{~L}$ pots with autoclaved soil, using 5 seeds per pot. The experiment was conducted in a randomized complete block design with 4 replicates. The following treatments were studied: 1) plant (control), 2) plant $+T$. harzianum (TH), 3) plant + SSB, 4) plant $+T$. harzianum + SSB $(S S B+T H)$. The amount of SSB applied to the soil was $20 \mathrm{~g}$ per pot, which represents $0.5 \%$ of the total soil weight used in each pot. The SSB was applied 15 days before soybean planting, and was completely incorporated into the soil.

The fungus $T$. harzianum was obtained from the commercial product Tricodermi ${ }^{\circledR}$, strain 1306 , cultivated in PDA (potato- dextrose-agar) culture medium. T. harzianum was applied to the soil two times, once at eight days before planting and the other at the time of planting, establishing an application of $40 \mathrm{~mL}$ per pot of the conidial suspension at a concentration of $1 \times 10^{6}$ conidia $\mathrm{mL}^{-1}$, using distilled-sterilized water.

\section{Evaluations of plant development}

The evaluations began on the eighth day after sowing the cultivars, adopting a system for observations every 48 hours. The variables evaluated were percentage of seed germination (PSG), number of pods, and fresh mass and dry mass of the plants in each pot. The PSG was established 13 days after sowing, obtained from the number of emergent seedlings per pot. The number of pods was determined at the end of the experiment, counting the number of fully formed pods per pot. At 87 days after germination, the soybean plants were collected and weighed to obtain the fresh mass, considering both the aerial part and roots. Subsequently, they were dried in a forced circulation oven, at $60 \stackrel{\circ}{ } \mathrm{C}$ for 48 hours. After this period, it was verified that the mass ( $\mathrm{g}$ ) of the plants had stabilized, and consequently a new evaluation was performed, representing the dry mass of the aerial part and roots.

\section{Statistical analysis}

The analyses were performed using the IBM SPSS Statistics program, version 23.0 (IBM, 2015). Data was submitted to analysis of variance and means were compared by the Duncan test $(p<0.05)$.

\section{Conclusion}

The agronomic indices (germination, number of pods, fresh and dry mass) evaluated in this study demonstrated that the use of SSB together with $T$. harzianum caused better development of soybean plants. The results reported in this study indicate synergism between SSB and T. harzianum, and that the combined application of these two products is a biological technology alternative that can be used to sustainably increase crop productivity.

\section{Acknowledgements}

L.E.B. Blum and C.C. Figueiredo thank CNPq (Conselho Nacional de Desenvolvimento Científico e Tecnológico) for the Research Productivity Fellowship.

\section{References}

Abrishamkesh S, Gorji M, Asadi H, Bagheri-Marandi GH, Pourbabaee AA (2015) Effects of rice husk biochar application on the properties of alkaline soil and lentil growth. Plant Soil Environ. 61: 475-482.

Ayres R, Stott R, Lee DL, Mara DD, Silva SA (1991) Comparison of techniques for the enumeration of human parasitic helminth eggs in treated wastewater. Environ Technol. 12:617-623

Caballero JA, Front R, Marcilla A, Conesa JA (1997) Characterization of sewage sludges by primary and secondary pyrolysis. J Anal Appl Pyrolysis. 4041: 433-450. 
Cézar R, Silva M, Colonese J, Bidone E, Egler S, Castilhos Z, Polivanov $H$ (2012) Influence of the properties of tropical soils in the toxicity and bioavailability of heavy metals in sewage sludge-amended lands. Environ Earth Sci. 66: 2281-2292.

Deenik JL, Cooney MJ (2016) The potential benefits and limitations of corn cob and sewage sludge biochars in an infertile oxisol. Sustainability. 8: 1-18.

Faria WM, Figueiredo CC, Coser TR, Vale AT, Schneider BG (2018) Is sewage sludge biochar capable of replacing inorganic fertilizers for corn production? Evidence from a two-year field experiment. Arch Agron Soil Sci. 64: 505519.

Furtado GF, Chaves LHG, Sousa JRM, Arriel NHC, Xavier DA, Lima GS (2016) Soil chemical properties, growth and production of sunflower under fertilization with biochar and NPK. Aust J Crop Sci. 10: 418-424.

Graber ER, Frenkel O, Jaiswal AK, Elad Y (2014) How may biochar influence severity of diseases caused by soilborne pathogens? Carbon Manag. 5: 169-183.

Graber ER, Harel YM, Kolton M, Cytryn E, Silber A, David DR, Tsechansky L, Borenshtein M, Elad Y (2010) Biochar impact on development and productivity of pepper and tomato grown in fertigated soilless media. Plant Soil. 337: 481496.

Han F, Ren L, Zhang X-C (2016) Effect of biochar on the soil nutrients about different grasslands in the Loess Plateau. Catena. 137: 554-562.

Hu L, Cao L, Zhang R (2014) Bacterial and fungal taxon changes in soil microbial community composition induced by short-term biochar amendment in red oxidized loam soil. World J Microbiol Biotechnol. 30: 1085-1092.

Ibm Corp (2015) Released 2015. IBM SPSS Statistics for windows, Version 23.0. Armonk, NY: IBM Corp.

Ibrahim M, Li G, Khan S, Chi Q, Xu Y (2017) Biochars mitigate greenhouse gas emissions and bioaccumulation of potentially toxic elements and arsenic speciation in Phaseolus vulgaris L. Environ Sci Pollut Res. 24: 1952419534.

Khomari S, Golshan-Doust S, Seyed-Sharifi R, Davari M (2018) Improvement of soybean seedling growth under salinity stress by biopriming of high-vigour seeds with salttolerant isolate of Trichoderma harzianum. New Zeal J Crop Hort Sci. 46: 117-132.
Kraska P, Oleszczuk P, Andruszczak S, Kwiecińska-Poppe E, Różyło K, Pałys E, Gierasimiuk P, Michałojć Z (2016) Effect of various biochar rates on winter rye yield and the concentration of available nutrients in the soil. Plant Soil Environ. 62: 483-489.

Li R-X, Cai F, Pang G, Shen Q-R, Li R, Chen W (2015) Solubilisation of phosphate and micronutrients by Trichoderma harzianum and its relationship with the promotion of tomato plant growth. PLoS ONE. 10: e0130081.

Muter O, Grantina-levina L, Makarenkova G, Vecstaudza D, Strikauska S, Selga T, Kasparinskis R, Stelmahere S, Steiner C (2017) Effect of biochar and Trichoderma application on fungal diversity and growth of Zea mays in a sandy loam soil. Environ Exp Biol. 15: 289-296.

Pereira JL, Queiroz RML, Charneau SO, Felix CR, Ricart CAO, Da Silva FL, Steindorff AS, Ulhoa CJ, Noronha EF (2014) Analysis of Phaseolus vulgaris response to its association with Trichoderma harzianum (ALL-42) in the presence or absence of the phytopathogenic fungi Rhizoctonia solani and Fusarium solani. PLoS ONE, 9: e98234.

Rajendiran R, Jegadeeshkumar D, Sureshkumar BT, Nisha T (2010) In vitro assessment of antagonistic activity of Trichoderma viride against post harvest pathogens. J Agric Technol. 6: 31-35.

Scheifele M, Hobi A, Buegger F, Gattinger A, Schulin R, Boller T, Mäder P (2017) Impact of pyrochar and hydrochar on soybean (Glycine max L.) root nodulation and biological nitrogen fixation. J Plant Nutr Soil Sci. 180: 199-211.

Shukla SK, Shee S, Maity SK, Solomon S, Awasthi SK, Gaur A, Pathak AD, Jaiswal VP (2017) Soil carbon sequestration and crop yields in rice-wheat and sugarcane-ratoon-wheat cropping systems through crop residue management and inoculation of Trichoderma viride in Subtropical India. Sugar Tech. 19: 347-358.

Vecstaudza D, Grantina-levina L, Makarenkova G, Kasparinskis R, Selga T, Steinberga V, Stelmahere S, Steiner C, Muter O (2018) The impact of wood-derived biochar on the survival of Trichoderma spp. and growth of Secale cereale L. in sandy soil. Biocontrol Sci Technol. 28: 341358.

Yuan H, Lu T, Wang Y, Chen Y, Lei T (2016) Sewage sludge biochar: nutrient composition and its effect on the leaching of soil nutrients. Geoderma. 267: 17-23. 